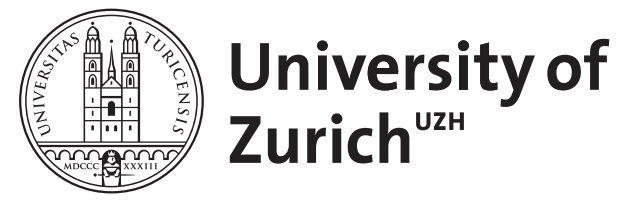

Iatrochemistry and Paracelsism in the Ottoman Empire in the Sixteenth and Seventeenth Centuries

\author{
Bachour, Natalia
}

DOI: https://doi.org/10.1163/2212943X-00601008

Posted at the Zurich Open Repository and Archive, University of Zurich ZORA URL: https://doi.org/10.5167/uzh-145756

Journal Article

Published Version

Originally published at:

Bachour, Natalia (2018). Iatrochemistry and Paracelsism in the Ottoman Empire in the Sixteenth and Seventeenth Centuries. Intellectual History of the Islamicate World, 6(1-2):82-116.

DOI: https://doi.org/10.1163/2212943X-00601008 


\title{
Iatrochemistry and Paracelsism in the Ottoman Empire in the Sixteenth and Seventeenth Centuries
}

\author{
Natalia Bachour \\ University of Zurich \\ natalia.bachour@aoi.uzh.ch
}

\begin{abstract}
The sixteenth and seventeenth centuries saw the spread of iatrochemistry. In the second half of the seventeenth century, European iatrochemical knowledge was introduced into the Ottoman Empire through translations from Latin into Arabic. This study addresses the adoption and adaptation of this new knowledge by examining these works, as well as the medical compendium of Dāwūd al-Anțākī and the only book written by Ibn Sallūm himself. European medical texts underwent a transformation process on a textual as well as on a conceptual level, especially regarding Paracelsism. Even before that, Dāwūd al-Anțākī's book already contains alchemical procedures and mineral remedies for internal application, which might be described as a precursor of medical chemistry.
\end{abstract}

\section{Keywords}

Iatrochemistry - Paracelsism - Ottoman medicine - Dāwūd al-Anțākī - Ṣālị̣ b. Nașrallah b. Sallūm al-Halabī

\section{Introduction}

The sixteenth century is marked by world-historical change. Spain and Portugal colonised the New World and explored the oceans. In Europe, Humanism, the Renaissance, and the Protestant Reformation gave new impulses to intellectual life and science. These changes in their turn influenced medicine. New diseases such as syphilis spread worldwide; new plants and cures found their way to Europe; and revolutionary new medical concepts and therapies 
emerged. Andreas Vesalius (1514-1564) published his influential work on human anatomy, De humani corporis fabrica (On the Fabric of the Human Body). William Harvey (1578-1657) described the circulation of blood. Both proved by observation and experimentation that certain of Galen's assumptions were false. Besides, the traditional school of Galenic medicine was confronted with a new doctrine called nova medicina, rooted in alchemy, astrology, magic and natural philosophy. It was attributed to the Swiss-German physician Theophrastus Philippus Aureolus Bombastus von Hohenheim (c. 1493-1542), better known as Paracelsus, who broke with the orthodox medical doctrine based on humoural pathology. The university-based traditionalists or Galenists, however, rejected Paracelsus's new medical doctrine, as well as his alchemical remedies. Paracelsists and Galenists represented two antagonistic, even hostile competitors. $^{1}$

In the early seventeenth century, conciliatory tendencies arose, especially as some remedies developed by Paracelsus or his followers, the Paracelsists, such as Oswaldus Crollius (c. 156o-16o8), proved efficacious in healing some diseases. As the century progressed, the boundaries between the rival schools gradually began to disappear. This development was marked by a book by the eclecticist Daniel Sennert (1572-1637), professor of medicine at the University of Wittenberg, De chymicorum cum Aristotelicis et Galenicis consensu ac dissensu (On the Agreement and Disagreement of the Chemical Authors with the Aristotelians and Galenists), published in 1619. Medical chemistry (or iatrochemistry) gradually came to be integrated into the framework of academic medicine, having largely emancipated from the medical, astrological, and magical philosophical concepts of Paracelsism. ${ }^{2}$

During the sixteenth and seventeenth century, the Ottoman Empire was a powerful realm controlling south-eastern Europe, western Asia, and north Africa. As a multi-ethnic and multilingual empire, it was the ideal locus for scientific and technological exchange between eastern and western cultures. Ekmeleddin İhsanoğlu identified an era of 'Islamic science' that prevailed until the end of the sixteenth century. ${ }^{3}$ In the seventeenth century, he continues, the Ottoman Empire was gradually surpassed by the European states politically, socially and scientifically, and the Ottomans adopted the technical achieve-

1 On the developments in medicine and pharmacy in the early modern period see Friedrich/ Müller-Jahncke, Geschichte, pp. 3-78; Porter, Greatest, chs. 8 and 9. On Paracelsism and the conflict between Paracelsists and Galenists see Friedrich/Müller-Jahncke, Geschichte, pp. 267-300.

2 See Friedrich/Müller-Jahncke, Geschichte, pp. 306-311, 322-325.

3 İhsanoğlu, "Ottoman Science," 2. 
ments that had emerged in Europe. İhsanoğlu refers to this phase as the period of 'Western science.' Nevertheless, the thesis of a centre-periphery transmission of knowledge has often been repudiated, most recently in Science Between Europe and Asia. The editors of that volume, Günergun and Raina, postulate "appropriation" and "filtering" as terms for understanding "the diversity of the processes underlying the adoption and adaptation of travelling ideas and techniques."4

Ottoman medicine included several medical traditions that existed in parallel. On the one hand, it represented a continuation of Graeco-Arabic medicine. On the other hand, it interacted with medical concepts and practices developed in other cultures. The latter process occurred by various means, such as translation or direct contact involving a variety of actors. Jewish and Greek physicians living in the Ottoman Empire, who had studied at European universities and mastered Latin, played a crucial role in the transmission of medical knowledge. ${ }^{5}$ In addition, Ottoman physicians were part of an elite of educated scholars proficient in Arabic, Persian and Turkish. ${ }^{6}$ Proficiency in Persian must have opened up another channel for the exchange of knowledge, namely with Indian medicine as, under Mughal rule, several medical works were translated from Sanskrit into Persian. ${ }^{7}$ As is well known, Ayurvedic medicine has a

4 Günergun/Raina, Science, pp. 1, 2, 9. On transmission of knowledge between Europe and the Ottoman Empire see Brentjes, Travellers from Europe; Küçük, Contexts and constructions.

5 For example Tobias Cohn (1652-1729), Daniel de Fonseca (1672-c. 1740), Ḥayātīzāde Muștafā Feyżī (d. 1692) (see Murphey, "Jewish Contribution," pp. 61-74; and Shefer-Mossensohn, "Tobias the Ottoman," pp. 45-66); Musa Calinus el-Israili (fl. 16th c.) (see Kahya, "Musa Calinus el-Israili," pp. 49-56.); and Musa Hamon (fl. 16th c.) (see Sarı et al., "Gedanken,” pp. 57$68)$.

6 See Shefer-Mossensohn, Ottoman Medicine, pp. 185-187.

7 For example Majmū'a-yi Shamsī (Collection of Shams) by Khwāja Shams Mustawfì that was likely compiled around or during the first decade of the fourteenth century (see Fabrizio Speziale "Majmū'a-yi Šamsī," Perso-Indica. An Analytical Survey of Persian Works on Indian Learned Traditions, eds. F. Speziale and C.W. Ernst, http://www.perso-indica.net/work/ majmua-yi_samsi; accessed 30 June 2015). Another work that contains the preparation and the uses of the oxides of different metals is Majmū'a-yi Żiyā' (Collection of Żiyā') written by Żiyā’ Muhammad Mas'ūd Rashīd Zangī 'Umar Ghaznawī during the reign of the sultan of Delhi, Muhammad b. Tughluq (r. 1325-1351) (see ibid., http://www.perso-indica.net/work/ medicine/majmua-yi_diya; accessed 3o June 2015). A further work of the fifteenth century is Tajribāt al-mujarrabāt-i Ghiyāth-shāhī (The experiences of the tested prescriptions of King Ghiyāth) by Sacd Allāh Nizāāī Zanjānī (ibid., http://www.perso-indica.net/work/medicine/ tajribat_al-mujarrabat-i_giyat-sahi; accessed 30 June 2015). Further translations from the sixteenth century can be found on http://www.perso-indica.net/work/medicine. 
long tradition of healing with minerals and chemical remedies. ${ }^{8}$ Ultimately, all these traditions were integrated in a protracted and continuous process that Shefer-Mossensohn describes aptly as the "localisation and Ottomanisation" of medicine. ${ }^{9}$

Nevertheless, the exchange of knowledge between the Ottoman Empire and its neighbouring cultures with regard to iatrochemistry has not yet been thoroughly addressed. ${ }^{10}$ To explore the underlying process, several factors need to be considered with regard to classical Islamic medicine, to Ayurvedic medicine in Persian translations, to European medicine, and to 'Ottoman' medicine. In the second half of the seventeenth century, translations from Latin into Arabic were commissioned by the imperial chief physician Șaliḥ b. Nașrullāh Ibn Sallūm al-Halabì (d. 1669). Nevertheless, we must consider the existing recipes and remedies that contain mineral and chemical substances in Ottoman medical compendia prior to these translations. Therefore, the present contribution also examines the encyclopaedic work Tadhkirat ülì al-albāb wa-al-jāmic lil'ajab al-ujāb (Memoranda of the Intelligentsia and Compendia of Curiosities) by the Ottoman physician Dāwūd al-Anțākī (d. 1599), often regarded as a scholar of classical Islamic medicine, and compares the relevant paragraphs with Ibn Sinā's (d. 1037) al-Qanūn fìal-tibb (Canon of Medicine) to identify the novel content in the Tadhkira. In addition, this study addresses the works translated on behalf of Ibn Sallūm: Ghāyat al-itqānfì tadbìr badan al-insān (Utmost Perfection in the Treatment of the Human Body), al-Tibb al-kimiyā̇al-jadìd (The New Chemical Medicine), which includes al-Kimiyä al-malakiya (The Royal Chemistry), and Tarjamat al-Aqrābādhin al-jadīd (The Translation of the New Antidotarium). Finally, it addresses $\dot{G} \bar{a} y e t$ ül-beyān fì tedbìr beden il-insān (Utmost Explanation in the Treatment of the Human Body), the only work demonstrably authored by Ibn Sallūm himself. This study shows that medical chemistry already existed in Arabic medical compendia prior to the works contributed to Ibn Sallūm, although the translations from Latin into Arabic and Ottoman played a crucial role in the adaptation of European iatrochemistry and the shaping of 'Ottoman' medicine.

8 See for example Wujastyk, "Perfect Medicine: Mercury in Sanskrit Medical Literature;" Dash, Alchemy and metallic medicines in Āyurveda.

9 See Shefer-Mossensohn, Ottoman Medicine, pp. 182-185.

10 Bachour's study mainly adresses Paracelsism (Bachour, Oswaldus); see the contributions of Sarı (Sarı, "Ottoman Medical Practise," pp. 5-89; Sarı/Zülfikar, "The Paracelsusian Influence," pp. 157-179) and of Savage-Smith (Savage-Smith, "Drug Therapy," pp. 3-28). 


\section{Chemical Remedies in Dawūd al-Anțākī’s Tadhkirat ūlē al-albāb}

In classical Arabic medicine, as Ullmann suggests, a separation between alchemy and medicine regarding the philosophy of healing and the preparation of compound medicines existed. ${ }^{11}$ Nevertheless, if we examine the Tadhkira of al-Anțākī we find several indicators of the integration of alchemical praxis into medicine. Fabian Käs already noticed that al-Anțākī must have utilised alchemical texts in order to describe the formation of minerals, and that he was acquainted with alchemical Decknamen or pseudonyms, using them to indicate some minerals. ${ }^{12}$ The Tadhkira includes further evidence for al-Antākì's alchemical knowledge, and of its integration into the preparation of remedies.

First of all, al-Anțākì explains in detail certain alchemical procedures used to prepare some substances, while Ibn Sīnā merely mentions these substances. For example, in Ibn Sīnās Canon of Medicine, the "clay of philosophy" (tìn alhikma) is mentioned twice without further elaboration. ${ }^{13}$ Al-Antākī, however, explains its preparation method:

The clay of philosophy is a clay needed in medicine to stabilise the distillation apparatus to broil it. To prepare it, take one part of pure clay (țin khäliș), half a part of triturated coal (faḥm mashūq), cut hair (sha'r maqșūss), calcinated salt (milh mukallas), marsh mallow (khițī̄), slag of iron (khabath al-hadid), calcinated eggshell (kils qishral-bayd). Sieve [the mixture] and knead it thoroughly with saliva (aliba), vinegar (khall) or milk (laban). The more fermentation it undergoes, the more sufficient it is. ${ }^{14}$

Ibn Sīnā indicates that tutty (tūtiya $)$ can be prepared by sublimation, but there is no description of a sublimation method..$^{15}$ In al-Anțāki's Tadhkira, again, a concrete method is described:

Tutty $(t \bar{t} t i y \bar{a})$ is either natural [...] or artificial [synthesised] from triturated calamine (iqlimiy $\bar{a}$ ). If doused in portions through the cup of an

\footnotetext{
11 Ullmann, Medizin, p. 129.

12 Käs, Mineralien, p. 193. For example 'aqrab (scorpion) as a pseudonym for sulfur (kibrït), 'uqāb (eagle) for ammoniac salt (nūshādar), al-unthā (female) for mercury (zi'baq), 'alam (banner) for arsenic (zirnīkh) etc. (al-Anțākī, Tadhkira, vol. 1, pp. 239, 184).

13 Ibn Sīnā, Qānūn, vol. 3, pp. 1113, 1545.

14 Anțākī, Tadhkira, vol. 1, p. 234.

15 Ibn Sīnā, Qānūn, vol. 2, pp. 752-753.
} 
aluthel on melted copper, it sublimates and can be gathered in the same way as mercury is sublimated. ${ }^{16}$

Besides, al-Anțāki describes the distillation of several mineral spirits not mentioned by Ibn Sīnā. ${ }^{17}$ He even recommends some of them to be applied internally. ${ }^{18}$ The aqua of $b \bar{t} t \bar{a}^{c}\left(m \bar{a}^{3} b i t \underline{t} \bar{a}\right)$ was given by the governor of Aden (șăhib 'Adan) as a gift to the director of the Manșūie hospital in Cairo (șâhịib albìmāristān al-Manșūrī). It is used internally to heal the ulcers of the stomach (qurūḥ al-maida) and prepared as follows:

16 Anțākī, Tadhkira, vol. 1, p. 99. The same phenomenon is observed in other passages on mineral, animal and herbal substances. I give three further examples: While Ibn Sīnā merely mentions that the crystalline form of ammoniac salt (nüshädar) is the best sort of ammoniac, al-Anțākī gives detailed information on its various kinds and their extraction methods, differentiating between natural (țabīi) and artificial (mașnū') sorts. The latter are extracted during the sublimation (țașìd) of minerals in furnaces, or prepared by distillation (taqțīr) of the hair (Ibn Sīnā, Qānūn, vol. 2, p. 624; Anțākī, Tadhkira, vol. 1, p. 333). Secondly, Ibn Ṣinā merely writes that the oil of eggs (duhn al-bayḍ) is prepared by distillation. Al-Anțākī gives a concrete description of the procedure, which involves stuffing eggs in the cucurbita and distilling it several times (Ibn Sīnā, Qānūn, vol. 5, p. 2412; Anțākī, Tadhkira, vol. 2, p. 43). The third example is of ghäliya, an odoriferum composed of musk (misk), amber ('anbar) and aloes ('ūd), as al-Ṣahāāī, a disciple of Ibn Sīnā, explains in his medical lexicon, Kitāb al-Mā' (Ṣuhārī, Kitāb al-Mă', vol. 3, p. 111). Ibn Sīnā gives no description of the drug, simply stating that it was a common remedy (dawā'ma'rüf). AlAnțākī gives an elaborate description of the distillation methods of the drug, with several variations of the ingredients (Ibn Sīnā, Qānūn, vol. 2, p. 798; Anțākī, Tadhkira, vol. 1, p. 244).

17 Distillation was also used by al-Anțākī to identify the temperament of simples. Once distilled in the cucurbita and alembic, a simple drug separates into four parts: fluid ( $\left.m \bar{a}^{3} i^{c}\right)$, foam (zabad), sublimate (șā id) and solid (thābit), correlating with the elements water, air, fire and earth, respectively (Anțākī, Tadhkira, vol. 3, p. 186).

18 Mineral oils or spirits were a major component of iatrochemical remedies used in Europe. They were synthesised either from simple drugs, e.g. spirit of ammoniac salt (contains approximately $10 \%$ ammonia and ammonium carbonate), spirit of vitriol (contains approximately $3 \%$ sulphuric acid), spirit of salt (contains hydrochloric acid), and spirit of tartar (contains mainly potassium carbonate); or from a combination of minerals, sometimes in combination with herbal components such as the composed spirit of tartar (prepared from tartar, ammoniac salt and spirit of tartar) or the aromatised spirit of ammoniac salt (prepared from ammoniac salt in combination with aromatic herbals as cinnamon, cloves, bitter orange or nutmeg) etc. (Schneider, Lexikon, vol. 2, pp. 184-189; vol. 3 , pp. $38,39,59,125)$. The oils were more concentrated solutions than the spirits: for example, oil of vitriol contains approximately $75 \%$ sulphuric acid, compared to only $35 \%$ in spirit of vitriol (Schneider, Lexikon, vol. 3, pp. 38, 39). 
Take one part of ajwain (nānakhwāh) and cinnamon (dārșin̄ì), half a part of magnetite (maghnāțis) and pearl $\left(l u^{\prime} l u^{3}\right)$, and a quarter part of ammoniac salt (nüshädar). Triturate the ingredients, douse [the mixture] with ten times its quantity of distilled vinegar (khall mușa"ad) and distil it (tuqattar) three times. ${ }^{19}$

The aqua of marmiyāsūs ( $m \bar{a}$ marmiyāsūs) is attributed to Balīnās. ${ }^{20}$ It was used externally to remove haemorrhoids (bawāsir), vitiligo (bahaq) and cicatrices (wasm). A caustic mixture of several mineral acids must have resulted after distillation:

Take one part each of sweet and bitter salt (milh hulwwa-murr), nitrate of potash (milh andarānī), borax (bawraq), ammoniac salt (nüshädar) and hair (sha'r); half a part each of saltpetre (bārūd), alum (shabb), egghells (qishr bayd). Dissolve (tuhall), precipitate (tu'qad), triturate (tushaq) and douse [the mixture] with aqua of colocynth (mäal-hanzal) that contains one-tenth part of alkali (milh qalī) and [finally] distil it seven times. ${ }^{21}$

The aqua of mashar ( $m \bar{a}^{\prime}$ mashar) is a further distillate described in the Tadhkira. Al-Anțākī confirms that it is not lethal (qattāl), as had been thought, and that he has frequently applied it internally (saqaynāhu kathïran) against ulcers of the lung (qurūh al-ria), humid cough (su'äl raṭb) and blockages $(s u d u d)$. It was prepared by roasting one part each of saltpetre (bārūd) and ammoniac salt (nushādar) seven times in dough ('ajīn), triturating and mixing the mass with egg white (bayād bayd) and distilling the mixture. ${ }^{22}$ The distillate must have contained nitric acid. ${ }^{23}$

The aqua of the 'miracle drop' ( $m \bar{a}$ 'al-nuqta al-khāriqa) is prepared by taking one part tartar (tartīi), half a part of salt (milh), triturating them with nine parts of vinegar (khall) and distilling the mixture. ${ }^{24}$ After distillation, a

\footnotetext{
19 Anțākī, Tadhkira, vol. 1, p. 289.

20 Balīnās, an authority who is often cited in Arabic hermetic literature, might refer to the Neopythagorean Greek philosopher Apollonios of Tyana (d. 10o). See Ullmann, Geheimwissenschaften, pp. 176, 378 .

21 Anțākī, Tadhkira, vol. 1, p. 289.

22 Ibid., p. 290.

23 A similar method of dry distillation was described in al-Kimiy $\bar{a}$ ' al-malakiyya to prepare the spirit of saltpetre (rūh al-bārūd; compare Ibn Sallūm, al-Kïmiyä’’ Ayasofia 3671, f. $39^{\mathrm{v}}$ ).

24 Anțākī, Tadhkira, vol. 1, p. 29 .
} 
mixture of distilled vinegar and tartaric spirit must have resulted. According to al-Anțākī, the distillate destroys kidney stones (yufattitu al-hașā) and triggers the excretion of phlegmatic humours (akhlät lazija) if taken internally. Al-Anțākī notes that the spirit of the 'miracle drop' was invented by 'the shaykh' who recorded it in his books al-Mujarrabāt (The Tested Drugs) and al-Shifä' (The Healing) (mā̄al-nuqța al-khāriqa min istinbāț al-shaykh qarrarahū fi alShifǟ' wal-Mujarrabāt). The identity of the shaykh was discussed by Käs, who noted that this title refers to a "sinister astrologer" in connection with the book named $a l-S h i f \bar{a}$, whereas al-Anțākī refers to Ibn Sīnā as shaykh in reference to his Canon of Medicine. ${ }^{25}$ Al-Shifä' might be referring to Shifäa al-asqām wadaw ä al-älām ("Healing of Diseases and Cures of Pain"), a widespread medical compendium written by Ḥusām ul-Dīn el-Aydınī or Ḥācı Paşa (d. 1417), a physician who originated from Aydın in western Anatolia and lived in Egypt in the fifteenth century. ${ }^{26}$ Unfortunately, the work of this scholar has not yet been the subject of research, and therefore the identity of the shaykh remains unclear.

In addition to aqua of $b i t t \bar{a}^{c}$, of mashar, and of the miracle drop, al-Anțākī applies further alchemical preparations internally. He administers pearls as a solution in vinegar, in contrast to Ibn Sīnā who merely recommends triturating them thoroughly for good absorption because of their density (kathifat aljawhar). ${ }^{27}$ Another solution of pearls (mahlül al-lu'lu') was described in the Tadhkira, namely by putting the pearls into a bottle (qārüra), filling it with the sour juice of citron (hammā a bath until the pearls dissolve. ${ }^{28}$

Al-Anțākī applies the spirit of ammoniac internally as well. He distils ammoniac salt (nüshädar) with hair ('udhra), and uses the distillate as an antidote (akhraja al-samm).$^{29}$ Furthermore, to remove foreign matter stuck in the pharynx ('alaq), such as iron or thorns, al-Anțākì recommends a tested remedy ( $m i n$ mujarrabātinā) that contains one part shavings of magnetite (maghnāțis) dissolved with one-tenth part of ammoniac salt (nushädar). One dram (dirham) is to be drunk with the aqua of common rue ( $m \bar{a}^{3} a l$-sudhāb). If the foreign matter

25 Käs, Mineralien, p. 192.

26 See İhsanoğlu et al., Osmanlı Tıbbi, vol. 1, pp. 18-33. Shifă’al-asqām wa-dawā̄al al-älām was among the most popular medical books in the Ottoman empire, as Sabev's study on book inventories in private and public Ottoman libraries shows (see Sabev, "Medical Books," pp. 615-628).

27 Anțākī, Tadhkira, vol. 1, pp. 285, 295; Ibn Sīnā, Qānūn, vol. 1, p. 362.

28 Anțākī, Tadhkira, vol. 1, p. 195.

29 Ibid., vol. 1, p. 333. 
is not expelled from the body but has reached the stomach, one must drink a bitter drug like birthwort (shïh) or lupine (turmus) with vinegar (khall). ${ }^{30}$

Finally, al-Anțākī applies a chemical derivative internally whose internal application was highly controversal among Galenists in Europe, namely mercury and its derivatives. He recommends pills that were allegedly invented in the hospital in Cairo (mustahdath fì al-bìmaristān) against Persian fire (nār fārisī), syphilis (ḥabb [ifranjī]), chancroid ( $\bar{a} k i l a)$ and ulcers (qurūḥ) and that contain mercury, sulfur and sublimated mercury (sulaymānī) with other herbal purgatives. ${ }^{31}$ Another pill contains mercury, scammony, opium, musk and amber. $^{32}$ A third variety contains sublimated mercury with wheat flour, turmeric (kurkum), sulfur and olibanum (lubān). Al-Anțākī warns against using this kind of pills, though. ${ }^{33}$

Alchemical procedures and remedies were thus integrated into the Tadhkira of al-Anțākī, but what was the cause for this development? Was it initiated by contact with Indian, Persian, or European medicine, or was it an indigenous development? In the Tadhkira, we find many remedies that are related to Indian medicine, for instance, anūsh dārū, which mainly contains the syrup of Indian gooseberry (amlaj) mixed with several herbal ingredients. ${ }^{34}$ Al-Anțāki writes that a savant from India ('ärif min al-Hind) told him that anūsh dārū was used there against ophthalmitis and fevers (hakā lì 'ärif min al-hind annahum yustashfawn bihì min al-ramad wa-al-hummayāt). ${ }^{35}$ The use of mercury pills is another indicator of interaction with Ayurvedic medicine, possibly mediated through Persian texts. Already in 1501, the Persian physician Bahā' al-Dawla describes an electuary of mercury (majūn-i simmäb) containing the liquid metal in his medical compendium Khulāṣat al-tajärib (The Essence of Experiments) ${ }^{36}$ In 1511, al-Yūsufì describes a recipe for a mercury pill (habb-i sìmāb) which contains liquid mercury. ${ }^{37}$ In 1569, 'Imād al-Dīn Maḥmūd b. Mas'ūd b. Maḥmūd

$30 \quad$ Ibid., vol. 2, p. 125 .

31 Ibid., vol. 1, p. 117. The detailed preparation and other aspects of using mercury internally against syphilis are discussed in my contribution "Healing with mercury: the uses of mercury in Arabic medical literature."

32 Anțākī, Tadhkira, vol. 1, p. 184.

33 Ibid., vol. 2, pp. 48-49.

34 Ibid., vol. 1, p. 62; This remedy was already mentioned by Ibn Sīnā (see Qānūn, vol. 5: p. 2282).

35 Ibid., vol. 1, p. 62.

36 Bahā' al-Dawla, Khulāsat al-tajārib, p. 30o; Elgood, "Translation of a Persian," p. 484; see Thomann, "Early Persian Medical," pp. 971-996.

Yūsufî, Tỉbb-i Yūsufì, p. 77 . 
al-Ṭabīb compiled a treatise on syphilis, the Risālat-i ătishak (Treatise on Venereal Disease). ${ }^{38}$ He mentions several recipes for pills with mercury, or with mercury combined with sublimated mercury (sulaymānī), or with mercury combined with killed mercury. In contrast, mercury salve was typically used against syphilis in Europe in the sixteenth century. Mercury pills were introduced for that purpose in the middle of the sixteenth century but they were rarely used. ${ }^{39}$

Contacts with Europe can be also traced in the Tadhkira. Cinnabar (zunjufr) was imported from Venice ( jazāir al-Bunduqiyya), Armenia and from the Indus valley (huwa al-muta'āraf al-mutadāwal al-ān yujlab min nawāḥ̄ al-Sind waArminiyā wa-jazāir al-Bunduqiyya). ${ }^{40}$ The sublimated mercury sulaymānī was also brought from the region of Venice (a'mäl al-Bunduqiyya). ${ }^{41}$

Indigenous developments are very difficult to judge because the texts of physicians living between the fourteenth and sixteenth centuries have hardly been examined, not to mention the alchemical literature, which is still largely uninvestigated.

\section{Translations from Latin into Arabic}

In the seventeenth century, a translation movement initiated by the imperial chief physician Ibn Sallūm al-Halabi transmitted European iatrochemical knowledge into the Ottoman Empire. The arabophone Ibn Sallūm originated from Aleppo, where he studied and became head of the Aleppo hospital. After

38 Elgood "Translation of a Persian," pp. 476-478; 'Imād al-Dīn, Risāla-i ātishak, pp. 2628.

39 The first mercury pills that came into use in Europe were the so-called pillulae Barbarossae (Lesky, "Quecksilber," p. 3183). Barbarossa or Khayr al-Dīn Pasha (1466-1546), the famous Turkish corsair and Grand Admiral of the Ottoman fleet, who assumed the role of an intermediary between Francis I and Süleymān, gave its recipe to the king of France who was syphilitic (on Khayr al-Dīn Pasha, see Galotta, "Khayr al-Dīn Pāshā," EI, 2. ed). Lesky suggests that it was composed of raw mercury, flour, and laxatives. Wherever the corsair obtained the recipe, it originated from the East, or otherwise the physician at the court of Francis I would have known it. Sudhoff analysed a variety of recipes applied to treat syphilis at the turn of the fifteenth to the sixteenth century that originated in Germany, France and Italy. Recipes of mercury salve are largely dominent (Sudhoff, Frühgeschichte der Syphilis, pp. 61-79).

$40 \quad$ Anțākī, Tadhkira, vol. 1, p. 181.

41 Ibid., vol. 1, p. 198. 
entering the retinue of the governor of Aleppo, Ibşīr Mușțafā Pasha (d. 1655), he moved to Istanbul when the latter became Grand Vizier in 1654. Ibn Sallūm was appointed chief physician (re'is ül-ațibbā') at the hospital of Sultan Mehmed the Conqueror, and then became a physician of the palace $\left(a t \imath b b \bar{a}^{\prime}-\right.$ $\iota$ sultān $\bar{\imath})$. He was finally promoted to the position of imperial chief physician (hekimbaşı or re'ss ül-ațibbä) in 1656 or 1660 and remained in this office until his death in $1669 .^{42}$ Ibn Sallūm's descendants held high positions in the elite of educated scholars ('ilmīye), especially his son Yahyā Efendī and grandson Feyżullāh Efendī, who held the position of Rūmeli kā̇̇ı́askeri. ${ }^{43}$

Ibn Sallūm was interested in the medical developments occurring in Europe. Therefore, he commissioned a Christian physician named Niqūlāwūs to translate some renowned compendia into Arabic. ${ }^{44}$ This can be inferred from the preface and the closing part of the Aqrabādhìn Niqūlāwus (Antidotarium of Nicolas) or Tarjamat al-Aqrabādhin al-jadìd (Translation of the New Antidotarium). According to Nīqūlāwūs, the translation of this formulary was made at the request of Ibn Sallum who commissioned the translation of Sennert's medical compendium as well. ${ }^{45}$ We may conclude from this that Ibn Sallūm did not master Latin. Besides, we do not find in the bibliographic sources mentioning him any indicators on this subject. ${ }^{46}$

42 According to Ali Haydar Bayat, Ibn Sallūm was appointed chief physician of the Ottoman Empire (hekimbaşı or re'isülațibbāà) as the successor of Ḥammālzāde Meḥmed Efendī (d. 1656) in Shawwāl 1066/July 1656 (Bayat, Osmanlı, p. 69). However, Afyoncu claims that Ibn Sallūm was appointed only four years later, namely on 1o Dhū al-Hijja 1070/17 August 166o (Afyoncu, Osmanlılarda Sağlik, vol. 1, pp. 29-30, 35, 36, 81).

43 Bachour, Oswaldus, pp. 35-44.

44 Ibid., pp. $72-75$.

45 Ibid., pp. $73-75$.

46 Ibid., pp. 36-43; 49-5o. Miri Shefer indicates that Ibn Sallūm knew Latin because "he made several statements in his writings concerning this" (Shefer, “An Ottoman Physician," p. 137). Presumably she means the citations in the preface of al-Tibb al-kimiyā̄ al-jadìd in the first person narrative. Those phrases are verbatim translations from Sennert's De chymicorum cum Aristotelicis et Galenicis consensu ac dissensu, as a comparision with the Latin text revealed (see Bachour, Oswaldus, pp. 112, 115-120, 326-328; Sennert, De Chymycorum, pp. 1$35)$. 


\section{Tarjamat al-Aqrabādìn al-jadìd (Translation of the New Antidotarium)}

This antidotarium was translated by Nīqūlāwūs into Arabic. However, it mainly circulated in its Ottoman Turkish version as Terceme-i Akrabādīn-i cedìd or Aqrabādīn Süleymān Efendī after the name of the Ottoman physician Süleyman Efendi (d. 1716) who translated it into Ottoman and supported Nīqūlāwūs' completing it since work on the book stagnated after Ibn Sallūm's death. ${ }^{47}$ In the preface, Nīqūlāwūs narrates the story:

This book is the pharmacopoeia that is well regarded and widely used at this time, namely in the holy month of Ramadan, AH1092 [September/October 1681]. We began to complete this book at the request of one of the excellent and intelligent men, namely the chief physician in this great empire - may God elevate him forever — that is Șāliḥ Afandī b. Naṣr Allāh al-Ḥalabī [i. e. Ibn Sallūm; he said]: "I have a great desire for the book by Sennert, the German." It dealt with the treatment of all diseases. ${ }^{48}$ Then I translated and abridged the book [titled] "The Chemical Medicine." Then I translated and completed this book to the seventh treatise. Then he [Ibn Sallūm] passed away [...] and it [the book] remained uncompleted for a while. Then we completed and terminated it with the physician named Sulaymān Afandī b. Ibrāhīm, one of the royal physicians ... ${ }^{49}$

The Arabic version differs partly in the sequence of the chapters and treatises from the Ottoman translation. It contains thirteen treatises: the first ten deal with conventional remedies (electuaries, antidotes, purgatives, powders, pills, troches, collyria, syrups, dressings), the eleventh with remedies for nobles, the twelfth with popular remedies and the thirteenth treatise with chemical remedies, i.e. remedies that are prepared by using alchemical procedures and apparatuses. It includes twelve chapters on aqua distillata (muqațtarāt), spirits (arwāh), oils (adhān), elixirs (iksīrāt), tinctures (alwān), mineral acids (miyāh hâadda), extracts (khulāṣāt), salts (amlāh), sublimates (muṣa"adāt), calcinates (taklissāt), and magisteria (masijrät [sic]). ${ }^{50}$ Most of the remedies in the first ten treatises are attributed to a certain Nīqūlāwus or Ibn Māsawayh, identifications that lead us to Antidotarium Nicolai and Grabadin Mesue, the well-known

\footnotetext{
47 See Bachour, Oswaldus, p. 74.

48 Translation of Peter Pormann (Pormann, Mirror, p. 66).

49 See Bachour, Oswaldus, p. 75.

50 Ibn Sallūm, Tarjama: Ms Bağdadlı Vehbi 1374, ff. $1^{\mathrm{v}}-55^{\mathrm{r}}$.
} 
pharmacopoeia of the European thirteenth century compiled by Nicolas of Salerno and Pseudo-Mesue, respectively. ${ }^{51}$ However, the intertextuality of the Arabic text has not yet been sufficiently studied. ${ }^{52}$

\section{Al-Tibb al-kìmiyā'̄̄ al-jadìd (The New Chemical Medicine) and al-Kïmiyä al-malakiyya (The Royal Chemistry)}

Al-Tibb al-kimiyā̄ $\bar{\imath}$ al-jadìd has attracted the attention of many scholars of Islamic medical history, because it was thought to be a direct reception of Paracelsus, and therefore a testimony of Ibn Sallūm's Paracelsism..$^{53}$ In fact, the New Chemical Medicine combines translated sections from several Latin medical and pharmaceutical books, namely Daniel Sennert's Medical Institutions (Institutionum medicinae), On the Agreement and Disagreement of the Chemical Authors with the Aristotelians and Galenists (De chymicorum cum Aristotelicis et Galenicis consensu ac dissensu); Oswaldus Crollius's Treatise of Signatures (De signaturis internis rerum) and Wecker's Special Pharmacopoeia (Antidotarium speciale). In the extant manuscripts, al-Tibb al-kīmiyā̄a al-jadīd is inevitably followed by al-Kimiy ä al-malakiyya - the Arabic translation of Oswaldus Crollius's iatrochemical textbook The Royal Chemistry (Basilica chymica). These two texts were transmitted together as a unit and were both translated into Ottoman Turkish and Persian. ${ }^{54}$

Al-Tibb al-kimiya à $\bar{\imath}$ al-jadìd is composed of four treatises. ${ }^{55}$ In the preface, the translator gives a short definition of spagyric as the science of separation and aggregation, outlines its history, and legitimises it by describing the changing attitudes towards it after its evolution from mere alchemy (whose sole object was allegedly the transmutation of metal into gold) to a practice seeking to syn-

51 See Schmitz, Geschichte, vol. 1, pp. 377, 378, 383 .

$5^{2}$ The author is currently researching this topic.

53 For a detailed explanation see Bachour, Oswaldus, pp. 107-113.

54 See ibid., pp. 144-151. Other evidence of the unity of al-Tibb al-kimiyā's al-jadìd and alKimiy à al-malakiyya is the complementary structure, evidenced by anaphoric text references in al-Kimiyä' al-malakiyya as well as by the omission there of recipes already mentioned in al-Tibb al-kīmiyā's̄al-jadìd. A further error that was circulated in terms of the text history was the notion that al-Tibb al-kimiyā’̀ al-jadìd was a part of Ibn Sallūm's encyclopaedic work Ghāyat al-itqān fì tadbīr badan al-insān (see Bachour, Oswaldus, pp. 879o).

55 The following description of the composition of al-Tibb al-kimìyā' al-jadìd is taken from Bachour, Oswaldus, pp. 115-133. 
thesise cures in order to heal disease and preserve health. The first treatise is on natural philosophy or the theoretical principles of spagyric. The ten chapters contain explanations of the first matter (materia prima), elements, forms and species, animation, vital heat and spirit, the dogma of the three principles (i.e. salt, sulphur and mercury, the tria principia), generation and temperament, species generated from other species, transmutation (changing an external form but keeping its species-specific form), and the analogy between macrocosm and microcosm.

The second treatise deals with the principles of chemical medicine $(t i b b$ kimiy $\bar{a} \bar{\imath})$. The treatise gives explanations of the faculties of the human body, the pathology of diseases according to the doctrine of the three principles (tria principia) of salt, sulphur and mercury, and the Paracelsian concept of tartaric pathology. ${ }^{56}$ It outlines the semiotic of pulse and urine and gives an explanation of the cycles of diseases and fevers. It outlines the effects of the universal medicine, and lists sympathetic groups of drugs according to their signatures, i.e. their external characters, which symbolise their effects. The third treatise explains chemical operations in general. We find practical instruction in the preparation of medicaments, including on the degrees of heat, trituration, dissolution, calcination, corrosion, putrefaction, fermentation, maceration, decoction, collation, distillation, sublimation, coagulation, preservation and thickening. The fourth treatise, on the chemical operations of specific simples, contains two parts. The first deals with distillation methods for waters and spirits, the second with oils. Both parts open with general instructions on distillation, followed by specific distillation methods for plants, animals and minerals.

The four-treatise structure of al-Tibb al-kimiyāi al-jadìd represents the organisation of the older manuscript tradition to which this book belongs. Later manuscripts of the same work are subdivided into six treatises. The first treatise deals with natural philosophy, the second with the principles of chemical medicine, the third with the doctrine of signatures, the fourth with general chemical operations, the fifth with distillation methods for spirits, and the sixth with distillation methods for oils. This transmission line differs from its antecedent only in this restructuring, with no differences in the content or sequence of treatises and chapters. ${ }^{57}$

56 The concept that diseases are caused by coagulations of excremental salts as a result of external factors, just as tartar (a product of fermentation) precipitates in wine casks in storage (see Pagel, Paracelsus, pp. 153-156).

57 Bachour, Oswaldus, pp. 121-122. 
Thus al-Tibb al-kimiyā' $\bar{\imath}$ al-jadìd explains the theoretical principles, chemical operations in general, and instructions for the distillation of simples to prepare spirits and oils. However, it contains no recipes for the preparation of compound medicines. This gap was filled by al-Kimiy $\bar{a}^{\prime}$ al-malakiya, which mainly contains prescriptions for compound remedies. Al-Kimiy ä al-malakīya contains two treatises. The first treatise contains eight chapters on general cures, including digestives, emetics, cathartics, diuretics, diaphoretics, confortativa, analgesics and hypnotics, as well as odorifera. The second treatise is on specifica, or remedies for specific diseases. The sequence of the categories of specifica are altered to match the classical order used in the Arabic medical compendia, with diseases listed according to the organs affected (from top to toe), with non-organ-specific diseases discussed last. Each category contains the preparation method for one or several remedies, including chemical operations. ${ }^{58}$

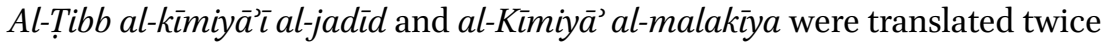
into Ottoman Turkish, the first complete Ottoman translation being $\dot{G} \bar{a} y e t$ ülmünā fitedbir il-mariz̄ $\bar{a}$ (Utmost Desire in the Treatment of Patients) by the physician Ḥasan Efendi and the second translation being Mürşid ül-elibbāfitercemet ispagiryā (Guide of Wise Men: the Translation of Spagyric) by the Ottoman Chief Physician Gevrekzāde Hāfız Ḥasan (1727-18o1). An anonymous abridgment of the first translation was circulated under the title $\dot{G} \bar{a} y e t$ ül-müterakki fì tedbir il-marżā (Utmost Goal in the Treatment of Patients). Apart from the complete translations of al-Tibb al-kimiyā̄ al-jadìd and al-Kimiya à al-malakìya, the first and second treatises of The New Chemical Chemistry (on natural philosophy and on the principles of the New Medicine, respectively) were also translated and integrated into medical compendia written in Ottoman Turkish. 'Ömer b. Sinān el-İznīkī (b. 1704?) integrated the two theoretical treatises into his compendium Şifä̉ ül-müminin (Healing of the Believers). 'Ömer Şifā'ì el-Burūsavī (d. 1742) integrates the preface, the first treatise, and the first six chapters of the second treatise into his book Kitāb uț-țbb il-cedìd il-kimiyā̄à (New Chemical Medicine). ${ }^{59}$

$5^{8} \quad$ Ibid., pp. 155-159, 206-224.

59 For more details on the translation into Ottoman see Bachour, Oswaldus, pp. 363-373. 


\section{Ghāyat al-itqān fì tadbīr badan al-insān (Utmost Perfection in the Treatment of the Human Body)}

The most extensive medical work attributed to Ibn Sallūm is Ghāyat al-itqānfi tadbìr badan al-insān, which was completed posthumously. Yahyā Efendī, the son of Ibn Sallūm, charged Aḥmad Abū al-Is'ād with putting the manuscripts of Ibn Sallūm into order, as the latter died before he could accomplish the compilation of this work..$^{60}$ Ghāyat al-itqān was translated into Ottoman Turkish by Ebū l-Feyż Mușțafā Efendi (d. 1747), under the title Nüzhet ül-ebdān fì tercemet Ghāyat al-itqān (Promenade of the Body in the Translation of the Utmost of Perfection) in 1728. Interestingly, Ibn Sallūm's grandson, Feyżullāh Muștafā, had commissioned the translation. ${ }^{61}$

Ghāyat al-itqān is divided into four treatises (maquala). ${ }^{62}$ The first is on general pharmacognosy, and contains three parts $\left(j u z^{\prime}\right)$. The first is dedicated to the general principles of drug composition, to natural simples, and to artificial remedies. The second part deals with pharmacological aspects and contains categories of drugs according to their faculties or according to the humours of the body. The third part deals with the chemical preparation methods of remedies in general, such as calcification, distillation, precipitation, and solvation. The texts were translated from the fifth book of Sennert's Medical Institutions and from Johann Jacob Wecker's (1528-1586) General Pharmacopoeia (Antidotarium Generale).

The second treatise is a formulary (aqrāba adhin) containing two parts: the first deals with internal remedies (such as syrups, distillations etc.) and the second with external remedies (oils, salves, plasters etc.). The chapters are based on Wecker's Special Pharmacopoeia, books two and three. The third and fourth treatises are on pathology. The third treatise deals with organ-specific diseases, arranged after the classical principle from top to toe. It is based on Sennert's Medical Practice (Practica medicina) (the first four books) and Treatise of Arthritis (De arthritide tractatus). The fourth deals with non-organspecific diseases: fevers, tumours, aesthetic modelling diseases (amrä d al-zina) and intoxication. It is based on Sennert's Medical Practice (books five and six) and Book on Fever (Defebribus).

For the sake of completeness, two further treatises must be mentioned. These were copied as an appendix to Ghāyat al-itqān. The first is Risāla fi bayān

\footnotetext{
6o Ibn Sallūm, Ghāyat al-itqān, Ms Ayasofya 3682, ff. XIV ${ }^{\mathrm{v}}-1^{\mathrm{r}}$.

61 Bachour, Oswaldus, p. 364.

62 More details on the structure and intertextuality of the treatises and chapters are presented in Bachour, Oswaldus, pp. 93-106.
} 
isqūrbūt (Treatise on Scurvy), an abridgement of Sennert's Treatise on Scurvey (De scorbuto tractatus). Here several chemical substances were recommended, such as spirit of vitriol (rụh al-zāj), tartareous vitriol (țarțarū wittrīyula $\bar{t} \bar{u})$, cream of tartar (qrīmù țarțir), spirit of salt (rüḥ al-milḥ) and diaphoretic antimony (antīmūn mu'arriq). ${ }^{63}$ The second treatise is Tarjamat risāla fi al-hummayāt al-radīa wa-al-wabä̉iyya (Translation of a Treatise on Malicious and Epidemic Fevers), an adaptation of the book by the Spanish physician Luís Mercado (1520-16o6), De febre pestillenti et de maligna ac de accidentibus, quae ijis et reliquis putridis succrescunt. This treatise contains no chemical remedies. ${ }^{64} \mathrm{In}$ addition to these books and treatises, several texts were wrongly attributed to Ibn Sallūm due to mistakes in the cataloguing of some manuscripts. ${ }^{65}$

\section{The Translation Procedure}

The compilation method for the translated medical compendia attributed to Ibn Sallūm resembles a cut-and-paste procedure. ${ }^{66}$ The translator first selected sections from several Latin compendia. The main criterion for the selection was pragmatic. For example, in De chymicorum cum Aristotelicis et Galenicis consensu ac dissensu, chapters dealing with the history of alchemy, Paracelsus's biography, magic and occultism, with atomism and with the conflict between the Galenists and the followers of Paracelsus were omitted. ${ }^{67}$ The translated segments were then combined into a complementary book that followed the classical organisation pattern of Arabic medical compendia, although the sequence of the chapters and sections might differ from the original text, or single recipes be integrated. In Ghäyat al-Itqān, some paragraphs were occasionally added that were not taken from Latin works: these included some remedies or commentaries of al-Anțākī and five recipes of Ibn Sallūm.

The translation process shows three characteristics, as revealed by a comparison of the complete text of al-Kimiy à al-malakiya with the source text of the Basilica Chymica: first the condensation of the text, then a practical orientation, and finally, an assimilation with the target culture. ${ }^{68}$ The text is condensed by omitting digressions and alternatives, and by streamlining the text so as to

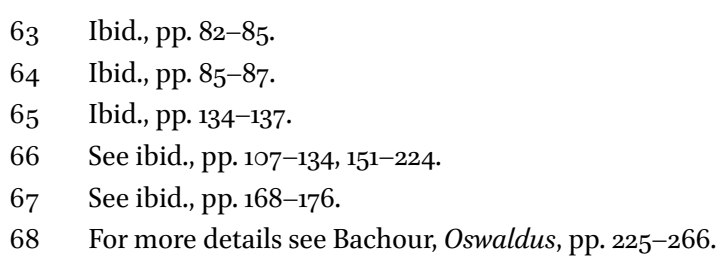


produce a clear manual of instruction for the preparation of chemical cures. With regard to the second aspect, the translator integrates his own expertise as an experienced alchemist into the Arabic text, adding, omitting or occasionally altering some specifications as to instruments, materials and time. The assimilation of the printed Latin texts with the customs of Ottoman manuscript culture was achieved by the elimination of structural markers such as numerations or headlines. The restructuring of the text according to the traditional pattern from top to toe also represents an assimilation.

\section{Paracelsism in the Ottoman Empire?}

In the sixteenth century, Paracelsus called for a new medicine (nova medicina). He broke with the orthodox medical doctrine, based on humoural pathology, because he was convinced that the healer should observe and learn from nature, rather than study ancient texts. His doctrine comprised diverse alchemical, astrological and magical conceptions that were in part ambivalent and even contradictory. On the one hand, Paracelsus considered illness to be a specific entity requiring a specific cure for its elimination; on the other, he postulated the theory of the three principles (salt, sulphur and mercury), in correlation with the three states of matter (solid, fluid and volatile) — as experienced by the alchemist in his laboratory. Salt, sulphur and mercury were thought to represent the immaterial principles of solidity, inflammability and volatility, respectively. Diseases were to be cured by remedies according to these principles. Paracelsus also used alchemical remedies in his therapy, including mercury and antimony derivatives applied internally, a practice unacceptable to Galenists. ${ }^{69}$

Some translated Latin texts contained Paracelsian ideas, especially the Royal Chemistry of the Paracelsist Oswaldus Crollius, or the eclectic work by Daniel Sennert, On the Agreement and Disagreement of the Chemical Authors with the Aristotelians and Galenists. This section summarises the mechanisms of translating Paracelsian ideas in al-Tibb al-kimiy $\bar{a} \bar{\imath}$ al-jadìd and al-Kimiy $\bar{a}$ ' almalakiyya according to the four aspects of transmission of medical, alchemical, astro-magical and religious concepts.

The concepts of the Paracelsian new medicine were assimilated. On the one hand, the translation is selective, with natural-magical, astrological, Christian

69 See on this Friedrich/Müller-Jahncke, Geschichte, pp. 280-285; Porter, Greatest, pp. 202205 . 
and mystical elements being ignored along with other elements deviating from humoural pathology, such as the refutation of the doctrine of qualities and degrees, or the debate on the principles of therapy ("the opposite is cured with the opposite" or "like cures like"). On the other hand, the translator has integrated the text into the field of humoural pathology by adding Galenic terms, or by substituting some Paracelsian terms with Galenic terms. Medical terms appear in the Arabic text, such as temperament (mizāj), the six nonnaturals (asbāb sitta darūriyya), humour (khilt), temperate (ta'dīl al-mizāj), or balanced temperament (mizāj mu'tadil). Although the first theoretical treatise of al-Tibb al-kimiyā $\bar{\imath}$ al-jadìd contains some Paracelsian concepts, such as the dualistic character of the elements, the three principles and tartaric pathology, these concepts have been assimilated in such a way that no obvious contradiction to Graeco-Arabic medicine remains. The translator's reserve in reporting these concepts demonstrates that al-Tibb al-kimiyā̄ al-jadìd does not represent a transmission of Paracelsism as understood in Europe, as an antithesis to humoural pathology.70

In the same way, the Paracelsian spagyric was demystified and represented purely as the art of preparing remedies by means of alchemical procedures. The Paracelsian term arcanum, which describes the subtle, hidden true medicine that is captured in crude shells and that must be freed by alchemical procedures, is simply translated as 'cure' $\left(\right.$ daw $\left.\vec{a}^{\prime}\right) \cdot{ }^{71}$ Nevertheless, the remedies of Paracelsus are highly praised in two passages that were added by the translator. The first praised remedy is diaphoretic antimony with gold, prepared by distilling sublimated mercury with antimony and adding the distillate to a gold solution of aqua regia. The precipitated product is finally broiled and used as a diaphoretic against a wide range of diseases. The translator writes: "Many people were treated with various remedies but have not been cured. When they took this blessed remedy they were relieved of their malignant diseases." ${ }^{\prime 2}$ With the same enthusiasm, the translator praises the analgesic and hypnotic remedies of Paracelsus, which contain extractions of opium, henbane (banj) and mandragora (lufäh): "The Galenists (ațibbä' Jalīnus) apply the hypnotic narcotics (mukhaddirät munawwima) but they [narcotics] remain toxic because they [Galenists] do not know how to separate their toxicity. We use these drugs as well but after preparation (tadbir) and separation of the toxicity (tafríq alsummiyya)."73

\footnotetext{
70 For more details see Bachour, Oswaldus, pp. 270-319.

71 Ibid., p. 321; for more details see ibid., pp. 319-329.

72 Ibn Sallūm, al-Kïmiy ä’ Ms Ayasofia 3671, f. 4 o r.

73 Ibid., f. $42 \mathrm{v}$.
} 
The assimilation of Paracelsian astro-magical concepts is also very clear. For instance, the term astrum (the invisible part present in all creatures that corresponds with the astral sphere and connects all astral bodies and terrestrial creations through sympathy and antipathy) is ignored in the translation, even though it represents the basis of natural magic. Nevertheless, some astromagical concepts are integrated by use of the concept of occult properties (khāsșa) to explain the effect of the weapon salve (marham armāriyā), a remedy which was applied to the weapon that had caused a wound and which was supposed to heal the injury it had made. However, the active ingredient of the salve was inaccurately translated or copied, namely "usnea"- the lichen that grows on the skull of a dead body hanged in open air and exposed to the light of the moon and other celestial bodies. The remedy contains, in the Arabic translation, "skull bones of a human" ('azm qahf al-insān). ${ }^{74}$ Furthermore, the correspondence between macrocosm and microcosm is represented merely as a relation of static analogy, and the doctrine of signature is reduced to the indication of sympathetic groups or drugs related (mansūba) to a certain organ or disease. This affinity is explained by the occult properties of the drugs and considered to be a gift of God. ${ }^{75}$ Additionally, the translator omits three remedies of the Basilica Chymica which are based on the magical concepts of antipathy and sympathy: two amulets that preserve from infection in the plague, "Xenexton of Paracelsus" (Zenexton Paracelsi) and "Xenexton for wealthy people" (Zenexton pro ditioribus), and the "Powder of horse-warts" (Pulvis ex callis equorum), which contains the warts of horses and was thought to be effective against convulsion of the hypochondrium or hysteria.

Finally, the translation of The Royal Chemistry omits all Christian elements, while adding some Islamic elements so that the integration of al-Kimiy $\vec{a}^{3}$ almalakiyya into Islamic scholarly culture is facilitated. Nevertheless, problematic substances from the point of view of religious law, such as wine or lard, are not systematically omitted. ${ }^{76}$ What was omitted, however, was the preparation of the human mummy (mumia hominis), religiously prohibited by fatwās. ${ }^{77}$ The extract of this drug was the main ingredient of the theriac of mumia homi-

74 Compare Ibn Sallūm, al-Kimiya $\bar{a}^{3}$ : MS Ayasofia 3671, f. $5^{2}$. with Crollius, Basilica, p. 243; see Bachour, Oswaldus, p. 339.

75 For more details see ibid., pp. 329-359.

76 Ibid., pp. 359-362.

77 Two fatāwa of Ebūssu'ūd Efendi (d. 1574) deal with human mummy. The first prohibits the medical use of the mummy of a person even if he has left a testimony approving this use for the benefit of Muslims, and the second prohibits the sale of mummified human flesh. See Düzdağ (ed.), Şeyhülislâm Ebussuud Efendifetvaları, p. 181. 
nis. In al-Kimiy $\bar{a}$ al-malakiyya, the theriac of mumia hominis was translated into Arabic, and many remedies for internal application contain this ingredient. Purchase lists of the royal palace prove that mumia hominis was indeed used in practice. ${ }^{78}$

\section{Ibn Sallūm al-Ḥalabī and the Ottomanisation of Iatrochemistry}

Although several medical compendia were attributed to Ibn Sallūm, the only work written by him is $\dot{G} \bar{a} y e t ~ \ddot{u l}-b e y a \bar{n}$ fì tedbìr beden il-insān (Utmost Explanation in the Treatment of the Human Body). This work was written in Ottoman Turkish and completed in 1664. As indicated in the preface, Ibn Sallüm compiled it at the demand of Sultan Mehmed IV (r. 1648-1687). He selected new rules, therapies, and preparations from renowned works that had not been mentioned by the ancients (selef). ${ }^{79}$

$\dot{G} \bar{a} y e t$ ül-beyān comprises four treatises. The first deals with the principles of regimen and diet, of bathing, cupping and bloodletting; the second is a pharmacopoeia, dealing in the first part with simple drugs and in the second with compound remedies arranged in ten chapters: syrups (şerbetler), electuaries and stomachics (ma'cunlar ve cevereşler), purgative electuaries (müshil olan ma'cunlar ve cevereşler), pills (hablar), troches (kırșlar), powders (sefüf), confections (la ük.), salves (merhemler), oils (yä $\dot{g} l a r)$ and collyria (şiyāflar); the third deals with pathology, covering organ diseases from top to toe; and the fourth treatise deals with non-organ-specific diseases, i.e. fevers, tumours, aesthetic modelling diseases (emräz ul-zine) and intoxication. The compendium ends with a chapter on 'tested remedies' (müjerrebāt), or remedies that act through their occult properties (virtutes). ${ }^{80}$

$\dot{G} \bar{a} y e t$ ül-beyān was translated twice into Arabic, by Muhammad al-Rayyis al-Ghazzī (d. 1718) and by Muḥammad b. Sharîf al-Ḥalabī in $1843 \cdot{ }^{81}$ Recently, an edition of this work was published by Muhammad Yāsir Zakkūr, who used both translations for his edition. However, the translators must have been

78 See my forthcoming contribution "Mūmiyā als Arznei im arabischen und osmanischen Schrifttum."

79 Ibn Sallūm, Ġāyet ül-beyān: Ms Köprülü 1/975, ff. $5^{\mathrm{r}}-5^{\mathrm{v}}$; see Bachour, Oswaldus, pp. 6671 .

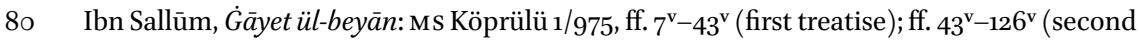
treatise); ff. $126^{\mathrm{v}}-26 \circ^{\mathrm{r}}$ (third treatise); ff. $26 \mathrm{o}^{\mathrm{r}}-298^{\mathrm{v}}$ (fourth treatise); ff. $298^{\mathrm{v}}-300^{\mathrm{v}}$ (epilogue).

81 Ibn Sallūm, Ghāyat al-Bayān (Arab.), p. 16. 
consulting the Arabic compendium Ghāyat al-itqān fì tadbìr badan al-insān since they adjoined passages that are not mentioned in the Ottoman compendium $\dot{G} \bar{a} y e t$ ül-beyān to their translated texts. A comparison of the chapter on syphilis $\left(d \vec{a}^{\prime}\right.$ ifranjī $)$ in the Arabic edition of Zakkūr with the Ottoman original reveals that Ibn Sallūm's caution on using mercury was omitted and that some recipes containing mercury were added. ${ }^{82}$ All of them were taken from Ghāyat al-itqān fì tadbìr badan al-insānn. ${ }^{83}$ The translator even added remarks in the first-person narrative pointing to the Arabic compendium Ghäyat alitqān. ${ }^{84}$

Considering the intertextuality of the Ottoman-Turkish $\dot{G} \bar{a} y e t$ ül-beyān, Ibn Sallūm must have used the translated works from Latin to compile this compendium. He used the pathological treatises of Ghāyat al-itqān to compile the corresponding chapters in $\dot{G} \bar{a} y e t$ ül-beyān. Nevertheless, Ibn Sallūm does not merely reproduce the translated chapters; rather, he selects, adds some comments indicating his opinion on the aetiology of some diseases, on their incidence in Istanbul or narrating some anecdotes from his medical practice. However, the quotation of the Greek authorities such as Hippocrates (Būkrāțt) and Galen (Cālīnūs) and of the classical Arabic authorities such as Ibn Sīnā and al-Rāzī are taken from Ghāyat al-itqān and subsequently they represent quotations at second hand, via the eclecticist Sennert who quotes Greek and Arabic, as well as European, authorities. Although Ibn Sallūm adds passages taken from Ottoman medical works, namely from al-Anțākīi, ${ }^{85}$ from Ibn Şerīf 'Alī Çelebi (fl. 15th c.), ${ }^{86}$ and from Ḥācı Paşa Celāleddīn el-Aydın̄i (d. 1417). From Hacı Paşa's

82 Compare the Ottoman version of $\dot{G} \bar{a} y e t$ ül-beyān fì tedbìr beden el-insān (Ibn Sallūm, Ġāyet ül-beyān: Ms Köprülü 1/975: ff. 281 v1 13-283 v) with the edited Arabic translation (Ibn Sallūm, Ghāyat al-Bayān (Arab.), pp. 868-875).

83 Compare the edited Arabic translation (Ibn Sallūm, Ghāyat al-Bayān (Arab.), pp. 868875) with the chapter on syphillis in Ghāyat al-Itqān fì tadbìr badan al-insān (Ibn Sallūm, Ghāyat al-Itqān, MS Ayasofya 3682, ff. $\left.281^{\mathrm{v}}, 18-284^{\mathrm{v}}, 16\right)$.

84 Four chapters contain such remarks: the chapter on sterility ('uqr) ends with the sentence wa-tamāmuhū mà 'allaqnāhu fí kitābinā Ghāyat al-itqān (a complete [description] is written in our book Ghāyat al-itqān); the chapter on putrid fever (hummā 'afaniyya) ends with the words: wa-tamām 'ilāj hādhihī al-ḥummā mā dhakarnāhu fì kitābinā Ghāyat al-itqān (the complete [description] of the treatment of this fever is mentioned in our book Ghāyat al-itqān); similar indications are found in the chapter on phlegmatic tumors (waram filaghmūn̄i) and on leprosy (judhām) (Ibn Sallūm, Ghāyat al-bayān (Arab.), pp. 737, 768, 841, 868 resp.).

85 Al-Anțāki is quoted in the chapters on syncope (ghashī), on intestine diseases (emräż ulam‘ā’) (Ibn Sallūm, Ġāyet ül-beyān: Ms Köprülü 1/975: ff. 185 $\left.5^{\mathrm{r}}, 203^{\mathrm{v}}\right)$.

86 Ibn Şerif's medical compendium is Yädigār fì al-țibb (Souvenir of Medicine) that was 
medical encyclopaedia Shifǟ al-asqām wa daw $\bar{a}$ al-älām (The Healing of Body and the Cures of Achiness), Ibn Sallumm adds a chapter on a disease called the collapse of the navel (göpeğin düşmesi) that was not mentioned by the ancestors (al-mutaqaddimūn). ${ }^{87}$

Regarding the pharmaceutical parts of $\dot{G} \bar{a} y e t$ ül-beyān, the aqrābādhin of the second treatise is based largely on Tarjamat al-Aqrabädhin al-jadìd. But, Ibn Sallüm experiments with the remedies before recommending them. ${ }^{88}$ The section on simples covers new herbs that were recently imported from the New World, or were not mentioned in the books of the ancients (al-mutaqaddimūn). The original texts might be taken from Wecker's Special Pharmakopoeia or Sennert's Medical Institutions. Ibn Sallūm used Ikhtiyārat al-badīi fí al-adwiya al-mufrada wa-al-murakkaba (Marvelous Selections of Simple and Compound Drugs) by the Persian physician 'Alī b. Ḥusayn al-Anșārī, called Ḥâjī Zayn al-'Aț̣ār (d. 1403), as indicated in the chapter on Nürüz otı (herb of Nowruz). ${ }^{89}$ In the section on simples, many drugs were praised with quotations of the Prophet Muhammad, a gesture of erudition and piety. ${ }^{90}$ The epilogue comprises remedies with occult properties $(k h a ̄ s ̣ s a) \cdot{ }^{91}$

Thus, Ġāyet ül-beyān fì tedbïr beden il-insān is an eclectic work. It adopts elements of Arabic prophetic medicine and literature on tested drugs, as well as Arabic, Ottoman and Latin medical literature of the medieval and early modern periods. The quoted authorities comprise a wide range, beginning with the Prophet Muhammad, and including the Ottoman physicians al-Anțākī, Hacı Paşa, Ibn Şerif, the Persian Zayn al-'Aț̣ār, Pseudo-Mesue (Māsawayh) and Nicholas of Salerno (Nīqūlāwus), the eclectic Sennert (Sanārtūs), and the "chemical doctors" (hukemä̀-ı kimyā viler), who were consistently quoted as

frequently copied (see İhsanoğlu, Osmanlı Tıbbi, vol. 1, pp. 78-83). Ibn Şerif is cited in the chapter on ileus (ilāwus), for example (see Ibn Sallūm, Ġāyet ül-beyān: Ms Köprülü 1/975, ff. $185^{\mathrm{r}}, 212^{\mathrm{r}}$ ), but he is not mentioned in Ghāyat al-itqān.

87 Ibn Sallūm, Ġāyet ül beyān: Ms Köprülü 1/975, f. 206 . The disease is caused by wind and water that are detained in the region around the umbilicus. The symptoms are pain and colic. This chapter is not mentioned in Ghāyat al-Itqān.

88 Ibid., f. 106' mention the compound medicines that have been tested).

89 Ibid., f. 100v . I owe the identification of this work to Muhammad Yāsir Zakkūr (see Ibn Sallūm, Ghāyat al-bayān, p. 271, footnote 3).

$90 \quad$ For example on narcissus (nercis), senna (senā), milk (süd), thyme (șa'tar) etc. (See Ibn Sallūm, Ġāyet ül beyān, MS Köprülü 1/975, ff. $7 \mathrm{O}^{\mathrm{r}}, 7 \mathrm{O}^{\mathrm{v}}, 72^{\mathrm{v}}, 76^{\mathrm{r}}$ resp.) It is worth mentioning that not all paragraphs about simples contain sayings of the Prophet. Ibid., ff. $299^{\mathrm{r}}-300^{\mathrm{v}}$. 
a group. Additionally, Ġāyet ül-beyān contains remedies, accounts and comments by Ibn Sallūm himself. ${ }^{92}$

$\dot{G} \bar{a} y e t$ ül-beyann gives the historian of medicine a very clear picture of the medical philosophy and practices followed by an Ottoman chief physician in the second half of the seventeenth century. Humoural pathology remains the framework of aetiology and therapy. Health is considered to be a state of balance between the four humours of the human body: blood, phlegm, yellow bile and black bile. Each of these is associated with two of the four primary qualities: hot, cold, dry and moist. Illness was thus an imbalance between the qualities or the humours of the body; it was to be removed by eliminating the excess of one humour by bloodletting or purging, or by giving a medicine that possessed its contrary quality. Nevertheless, Ibn Sallūm integrates chemical preparations, which he has tested himself, into this framework; he labels these as bizim mücerrebätımızdır (among our tested preparations) or mücerrebdir (tested). ${ }^{93}$

\section{Chemical Preparations Used in Istanbul}

Although Ibn Sallūm mentions several chemical remedies in $\dot{G} \bar{a} y e t$ ül-beyān and describes their effects and indications, he does not explain their preparation. ${ }^{94}$ In addition, the sections on compound drugs contain no chemical remedies. This gap was filled by Tarjamat al-Aqrābādhin al-jadìd, which contains a treatise on chemiatric preparations and by al-Tibb al-kimiyā $\bar{\imath}$ al-jadìd. These two texts must have played a crucial role in the transmission of iatrochemical knowledge, because they explain the chemical operations and provide recipes for preparing mineral drugs. Ottoman doctors and alchemists were able to manufacture iatrochemical derivatives themselves, rather than having to buy them from the 'Franks.' In his medical compendium Ġäyet ül-beyān $f i$ tedbir beden il-insān, Ibn Sallūm writes on salt of prunella: "The Franks bring it to Istanbul and sell it. Now they [the Franks] synthesise it in Istanbul, and we also synthesise it." ${ }^{95}$

\footnotetext{
92 On Ibn Sallūm's own remedies see Bachour, Oswaldus, pp. 66-71.

93 Bachour, Oswaldus, pp. 50-6o. A discussion of chemical preparations used by Ibn Sallūm follows.

94 Ibn Sallūm mentions several distilled spirits and oils by their names, he even mentions that they are distilled with cucurbita and alembic. These notes do not prove that he practiced alchemy (for examples see below).

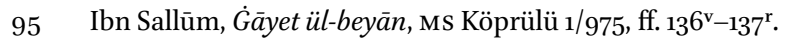


Ibn Sallūm describes in $\dot{G} \bar{a} y e t$ ül-beyān further preparations and herbal plants that were sold in Istanbul by the Franks. The spirit of vitriol ( $r u \bar{h} h a l-z \bar{a} j)$ was distilled by the Franks and brought to Istanbul to be sold. ${ }^{96}$ Galata seems to have played an important role in the trade of medical materials. Ibn Sallūm mentions that wax pessaries (bal mumundan fitil), angelica (ancelïkā) and masterwort (amberāțūryā) were brought from western Europe (Frengistān) and sold in Galata. ${ }^{97}$

What are the chemical preparations that the Ottoman physicians or druggists could synthesise following the instructions of the translated texts? Table 1 gives an overview of these chemical derivatives, arranged in chemical classes. The most important preparations are the antimony and mercury derivatives, which were indicated against a wide range of illnesses. Their use aroused a heavy debate between Galenists and Paracelsists in Europe, and served as an identifier of Paracelsists. Ibn Sallūm must have had his own reservations about the internal application of these remedies. He rarely mentions them in $\dot{G} \bar{a} y e t$ ül-beyān, and when he does so, it is without the laudatory epithets he uses when recommending the chemical remedies of the iatrochemists (hukema $\bar{a}^{3}-\iota$ kimyāviler). In the chapter on syphilis, he refers to the therapy with mercury (cive) by taking it internally as pills (habb) or by applying it externally as a salve (țllā), but he warns of the risks (muhătara). Consequently, these mercury preparations are to be applied under the supervision of a physician, and he will not give any further details. ${ }^{98}$ Ibn Sallūm mentions also that the Franks apply the glass of antimony (antimūniñ șı̧̧ası) and saffron of antimony (zaferān-ı ma'den̄̄) for quartan intermittent fever (hummāa-yı rüb'-i dāire). Nevertheless, he warns that not everybody would tolerate the glass of antimony and hence that it is to be applied only to persons of strong constitution. ${ }^{99}$ We conclude from this that Ibn Sallūm was not categorically against the internal application of antimony and mercury derivatives. He was, however, cautious with regard to its dangers.

The entries in the table show the wide variety of iatrochemical remedies introduced to the Ottoman Empire. But were these preparations merely pres-

96 Ibid., ff. $13 \mathrm{O}^{\mathrm{v}}$.

97 Ibid., ff. $238^{\mathrm{r}}, 25^{\mathrm{v}}$.

98 "But since this cure is dangerous and in need of a physician, we did not consider it" (lākin bu 'ilāc muhātạalı olmag̉la tabībe muhtācdur böyle oldığından biz terk eyleyüb yazmadık). Ibn Sallūm, Ġāyet ül-beyān, Ms Köprülü 1/975, f. $285^{\mathrm{v}}$.

"But since not everybody can tolerate it, it is to be applied only to persons of strong constitution and it should not be given to weak persons." (lākin buña herkes tahammül eylemez mizācı ḳavi ädamlara vereler za ïflere vermeyeler). Ibid., ff. $268^{\mathrm{v}}-269^{\mathrm{r}}$. 
TABLE 1 Inorganic iatrochemical substances described in translated works

\section{Antimony derivates}

Latin names

Mercurius vitae/ Flores butyri Mercury of live

antimonii

Vitrum antimonii

Flores antimonii

Antimonium diaphoreticum

Antimonium diaphoreticum

cum auro
English names

Glass of antimony

Flowers of antimony

Diaphoretic antimony

Diaphoretic antimony with gold
Arabic names

zi’baq al-hayāt

KM, 35r, 12

zujāj al-antīmūn

KM, $36 r, 1$

antīmūn mușa"ad

KM, 35V, 9

antīmūn mu'arriq sādhaj

KM, 4or, 4

antīmūn diyāfüritīkūn

KM, 4Or, 4

Mercury derivatives

Arcanum corallinum Paracelsi Red sublimated mercury

zi’baq marjānīḥulw

KM, 34V, 19

/ Mercurius sublimatus

rubeus non corrosivus

Turpetum minerale

Mineral turpeth

Mercury (II) acetate

tarbadh ma'dan̄̄

KM, 34r, 2

Terra foliata mercurialis

zi’baq mudabbaryuzīl

KM, 52r, 12

al-āthār țilāan

Vitriol derivatives

Tartarus vitriolatus

Vitriolum album vomitivum

Vitriolum veneris et martis
Tartar of vitriol

Emetic white vitriol

Vitriol of Venus and Mars țarțīral-zājal-musta'malfí KM, 32v, 13 al-inḍ̄j

al-zāj al-abyaḍ al-muqayyi $\quad$ KM, 33r, 20

zäjal-zuhra wa-l-marrīkh $\quad$ км, 46v, 23

Tartar derivatives

Cremor tartari

Spiritus tartari

Tartarus vitriolatus
Cream of tartar

Spirit of tartar

Tartar of vitriol qrimū țarțīr

KM, 33r, 10

rüh al-țarțir

KM, 4OV, 14

tarțīr al-zāj 
TABLE 1 Inorganic iatrochemical substances described in translated works (cont.)

Antimony derivates

Latin names

English names

Arabic names

Acetate derivatives

\begin{tabular}{llll} 
Crocus martis & Saffron of iron & zafarān al-hadìd & KM, 48r, 20 \\
Sal Jovis & Salt of Jupiter & milhal-mushtarī & KM, 47V, 3 \\
Saccharum Saturni & Sugar of Saturn & sukkar zuhal & KM, 51V, 12 \\
\hline
\end{tabular}

Magisteria / Calcium derivatives

\begin{tabular}{llll}
\hline Sal corallorum & Salt of corals & milh al-marjān & $\mathrm{KM}, 41 \mathrm{~V}, 13$ \\
Sal margaritarum & Salt of pearls & milh al-lü'tü & $\mathrm{KM}, 41 \mathrm{r}, 2 \mathrm{O}$
\end{tabular}

Sulphur derivatives

$\begin{array}{llll}\text { Lac sulphuris } & \text { Milk of sulfur } & \text { laban al-kibrīt } & \text { KM, 44V, } 15 \\ \text { Flores sulphuris } & \text { Flowers of sulfur } & \text { zahral-kibrït } & \text { KM, 49V, } 18\end{array}$

Mineral spirits

Spiritus salis

Spirit of salt

rüḥal-milh

KM, 39r, 5

Spiritus salis nitri

Spirit of saltpetre

rūḥ al-bārūd

KM, 39V, 7

Spiritus vitrioli

Spirit of vitriol

rūhal-zāj

TK, $25 \mathrm{~V}, 3$

Spiritus tartari

Spirit of tartar

rūh al-tarțīr

KM, 4OV, 14

Spiritus vini tartarisatus

Spirit of wine tartar

rūḥ al-sharāb ma' al-țarțīr

TK, 24V, 7

Spiritus sulphuris

Spirit of sulfur

$m \bar{a}^{3}$ al-kibrìt

TK, 25V, 18

Spiritus salis ammoniaci

Spirit of ammoniac salt

rūḥ al-nūshādar

TK, 26r, 3

Mineral oils

$\begin{array}{ll}\text { Oleum plumbi } & \text { Oil of lead } \\ \text { Oleum antimonii sacchari } & \text { Oil of sugar antimony } \\ \text { Oleum auri } & \text { Oil of gold } \\ \text { Oleum argenti } & \text { Oil of silver } \\ \text { Oleum perlarum } & \text { Oil of pearls } \\ \text { Oleum coralliorum } & \text { Oil of corals }\end{array}$

duhn al-usrub

TK, $28 \mathrm{~V}, 16$

antīmūn sukkarì

TK, $29 \mathrm{r}, 3$

duhn al-dhahab

TK, 29V, 8

duhn al-fida

TK, 3 or, 1

duhn al-lu'lu'

TK, 3 or, 12

duhn al-marjān

TK, 3or, 20 
Antimony derivates

\begin{tabular}{|c|c|c|c|}
\hline Latin names & English names & Arabic names & \\
\hline Oleum salis & Oil of salt & duhn al-milh & $\mathrm{TK}, 29 \mathrm{~V}, 2$ \\
\hline Oleum sulphuris & Oil of sulfur & duhn al-kibrīt & TK, 29V, 16 \\
\hline Oleum vitrioli & Oil of vitriol & duhn al-zāj & TK, 3 OV, 1 \\
\hline Oleum tartari & Oil of tartar & duhn al-țarțīr & TK, 3OV, 11 \\
\hline Oleum cupri & Oil of copper & duhn al-nuḥ̄s & TK, 31r, 5 \\
\hline Oleum ferri & Oil of iron & duhn al-hadìd & TK, 31r, 9 \\
\hline Oleum hydrargyri = & Oil of mercury & duhn al-zi’baq & TK, 31r, 16 \\
\hline \multicolumn{4}{|l|}{ Turpethum minerale } \\
\hline Oleum arsenic & Oil of arsenic & duhn al-zirnīkh & $\mathrm{TK}, 31 \mathrm{r}, 2 \mathrm{O}$ \\
\hline Oleum talci & Oil of talc & duhn al-țalq & TK, 31V, 7 \\
\hline Oleum crystallorum & Oil of crystal & duhn al-billawr al-ma'danī & TK, 31V, 11 \\
\hline \multirow[t]{2}{*}{ Oleum succini } & Oil of amber & duhn al-kahrabä' & KM, 44r, 1 ; \\
\hline & & & $28 \mathrm{r}, 15$ \\
\hline
\end{tabular}

Misc.

$\begin{array}{llll}\text { Sal prunellae } & \text { Salt of prunella } & \text { sālbürnella, } & \text { KM, 39v, } 15 \\ \text { Sal succini } & \text { Salt of amber } & \text { milhal-kahrabä } & \text { KM, 39v, 22 } \\ \text { Aurum fulminans } & \text { Essence of gold } & \text { dhahabal-ra'd } & \text { KM, 46v, 10 }\end{array}$

км: Ibn Sallūm, al-Kīmiyā̄o al-malakīya

TK: Ibn Sallūm, al-Tỉbb al-kìmiyà̄̄al-jadìd

ent in translated texts, or were they actually synthesised and used in medical practice? This question can be traced through the notes of Ibn Sallūm in his $\dot{G} \bar{a} y e t$ ül-beyān as he comments on the remedies he has applied himself with such remarks as mücerrebdir (tested) or bizim mücerrebātımızdır (we have tested it). A very important iatrochemical drug was cream of tar$\operatorname{tar}($ kirimmi țartarū $)$, used against melancholy, fever and constipation. ${ }^{100}$ Further chemical preparations were spirit of vitriol $(r \bar{u} h u z z-z \bar{a} c)$, prunella salt (sālparūnīlā or selc ül-hukema), prepared steel (pūlād-ı müdebber), saffron of iron (zaferān el-ḥadīdī), spirit of sulphur (kibrīt șuyu), sublimated sulphur

$100 \quad$ Ibid., ff. $136^{\mathrm{r}}, 263^{\mathrm{v}}, 286^{\mathrm{v}}, 287^{\mathrm{v}}$. 


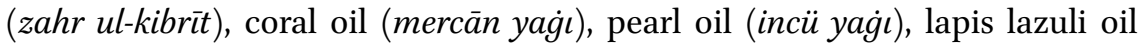

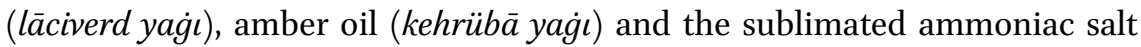
(mușa "ad nişādırı). ${ }^{101}$ We may suppose that the glass of antimony (antìmünin șıçası) and saffron of antimony (zaferān-ı ma'denī) were also in use. Regarding mercury, Ibn Sallūm does not specify which mercury derivatives were applied.

Several recipes for chemical preparations that do not exist in the original texts of Oswaldus Crollius were integrated into the translated text of al-Kimiy $\vec{a}^{2}$ al-malakiya. This implies that the translator added these instructions to explain how to synthesise these chemical preparations, which were probably widely used. These are the preparation methods of cream of tartar (qrimū tartīir), sublimated mercury (zibaq mușa"ad), flores antimonii or sublimated antimony (antīmūn mușa"ad), glass of antimony (zujāj al-antīmūn), prunella salt (sālbürnìlā), simple diaphoretic antimony (antīmūn mu'arriq sādhaj) and the essence of gold (dhahab al-ra'd). ${ }^{102}$

Other indicators of chemical remedies that might have been synthesised and applied in practice can be found in translated recipes in which the translator omitted, added or altered some specification in the work steps, such as materials, instruments, time limits etc. We conclude that at least the following preparations were synthesised by the translator: Gilla Theophrasti (zāj jilayyiqi li-l-akhlät al-ghalizza), flowers of sulfur (zahr al-kibrït), mineral turpeth (mercurius praecipitatus, tarbadh ma'danī), red sublimated mercury (zi'baq marjānī hulw), the specific purgative of Paracelsus (specificum purgans Paracelsi, mushil jāmi'min șan'at Barākilsūs), salt of amber (milh al-kahrubä), diaphoretic antimony (antīmūn dìyäüritī̄ūn) and salt of corals (milh al-marjān). ${ }^{103}$

The use of iatrochemical remedies in medical practice would certainly be an interesting avenue of research, but this would require the study of appropriate sources like physicians' casebooks, purchase lists of apothecaries or prescription books. ${ }^{104}$ Shefer-Mossensohn evaluated numerous "prescriptions made out by physicians and apothecaries for members of the Ottoman dynasty and high-ranking officials in the palace from the late seventeenth and eighteenth centuries" and arrived at the conclusion that the medical treatment remained

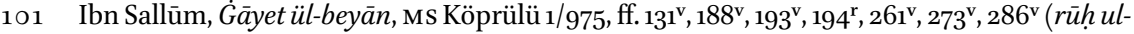

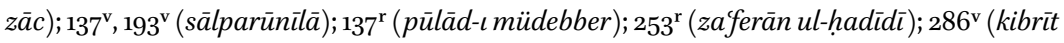
șuyu); $75^{\mathrm{v}}$ (zahr ül-kibrït); 141" ; $269^{\mathrm{r}}$ (mușa"ad nişādırı).

102 For further details on these preparations see Bachour, Oswaldus, pp. 177-191.

103 For further details on these preparations see ibid., pp. 247-259.

104 In Efraim Lev's study on the trade in medicinal substance, four minerals are mentioned: alum, arsenic, sulphide, vitriol and ammoniacum (see Lev, “Trade," pp. 175-176).
} 
based on "traditional botanical pharmacology"105 This result represents a contradiction between textual contents and medical practices and it would be interesting to explore this question in the future. ${ }^{106}$

\section{Conclusion}

This contribution has examined some stages of the development and formation of medical chemistry in the Ottoman Empire during the sixteenth and seventeenth centuries. The medical encyclopedia Tadhkirat ūlì al-albāb waal-jāmi' li-l-'ajab al-'̌jāb (Memoranda of the Intelligentsia and Compendia of Curiosities) by Dāwūd al-Anțākī was investigated with regard to alchemical procedures for the preparation of remedies and the application of chemical medicines in treatment, especially in terms of applying minerals as internal medicines. Al-Anțākī appears as an eclecticist who integrates magical, astrological, religious and alchemical elements into the framework of Graeco-Arabic medicine. He describes the preparation of mineral simples and compound remedies by alchemical procedures, such as sublimation, distillation, calcination etc., and administers sublimates, distilled spirits and oils in external and internal medicines, even mercury and sublimated mercury. Medical chemistry is an integrated part of al-Anțākī's medical encyclopaedia. However, the sources of his alchemical knowledge remain unexplored.

In addition, I addressed the translations from Latin into Arabic that were commissioned by Ibn Sallūm al-Halabī. They introduced iatrochemical knowledge from established European medical compendia into the Ottoman Empire, thereby undergoing a transformation process of selection, pragmatism and assimilation on a textual as well as on a conceptual level. The assimilation process is most obvious with regard to Paracelsian ideas. Comparing the Arabic translation al-Kìmiya al al-malakiyya with its Latin original, i. e. the Basilica Chymica by the Paracelsist Oswaldus Crollius, reveals that the translator was not at all interested in Paracelsism, with its components of natural magic and its opposition to humoural pathology, but rather in the art of preparing cures using alchemical methods.

Finally, I investigated Ibn Sallūm al-Halabī's work Gāayet ül-beyān fì tedbìr beden ül-insān. It represents a further integration of the knowledge that had

\footnotetext{
105 Shefer, "An Ottoman Physician," p. 144.

106 See in this respect Günergun's study on inorganic compounds in medical treatment (Günergun, 14-17. Yüzyıllarda Osmanlı).
} 
been introduced through translations. Furthermore, the book illustrates the process of shaping Ottoman medicine by selecting elements from a variety of medical cultures and integrating them into its characteristic framework. Ibn Sallūm produces a collage recombining selected elements from translated Latin works, as well as Persian and Ottoman encyclopaedias and works of prophetic medicine. Besides, his personal comments enrich the compendium and illustrate everyday life in Istanbul with regard to diseases or the availability of drugs.

\section{Bibliography}

\section{Primary Sources}

Al-Anțākī, Dāwūd b. 'Umar, Tadhkirat ūlī l-albāb wa-al-jāmi' lil-'ajab al-'ujāb, wa-bihāmishihī al-Nuzha al-mubhija fì tashhìdh al-adhhān wa-tádīl al-amzija lil-mu’allif aydan, two parts in one volume, Beirut: al-Maktaba al-Thaqāfiyya, [s. o.].

Bahā̄ al-Dawla, Rāzī, Khulāsat al-tajārib, ed. Muhammad Riẓā Shams Ardakānī, intr. 'Alī Akbar Wilāyatī, Tehran: Rāh-i Kamāl, 2008.

Crollius, Oswaldus, Basilica Chymica, continens philosophicam propria laborum experientia confirmatam descriptionem et usum remediorum chymicorum; Tractatus novus de signaturis rerum internis, Frankfurt am Main, 1611 (repr. Hildesheim/Zürich:Olms, 1996).

Ibn Sallūm, Șaliḥ b. Nașrullāh al-Ḥalabī, Ġāyet ül-beyānfìtedbür beden il-insān [Ottoman Turkish version], MS Istanbul, Köprülü 1/975, KK 975, copied 8 Jumādā II 1075/27 December 1664.

Ibn Sallūm, Șaliḥ b. Nașrullāh al-Halabī, al-Ṭibb al-kìmiyā̄ì al-jadīd, Ms Istanbul, Ayasofya 3671 , ff. $1^{\mathrm{v}}-31^{\mathrm{v}}$, copied 16 Aylūl 1087/16 September 1676 .

Ibn Sallūm, Șaliḥ b. Naşrullāh al-Ḥalabī, al-Kìmiyā’ al-malakīya, ms Istanbul, Ayasofya 3671 , ff. $31^{\mathrm{v}}-52^{\mathrm{v}}$, copied 16 Aylūl 1087/16 September 1676 .

Ibn Sallūm, Șalị̣ b. Nașrullāh al-Ḥalabī, Tarjamat al-Aqrābādīn al-jadīd, Ms Istanbul, Bağdadlı Vehbi 1374, ff. $1^{\mathrm{r}}-55^{\mathrm{v}}$, copied in Ramadan 1092/September-October 1681.

Ibn Sallūm, Șalị b. Nașrullāh al-Ḥalabī, Ghāyat al-ittān fì tadbìr badan al-insān, MS Istanbul, Ayasofya 3682, ff. 1-311', copied 1o Rabī' I 1135/19 December 1722.

Ibn Sallūm, Șaliḥ b. Nașrullāh al-Ḥalabī, Ghāyat al-bayān fìtadbïr badan al-insān [translated Arabic version], ed. Muhammad Yāsir Zakkūr, Damascus: al-Hay’a al-Āmma lil-Kitāb, 2013.

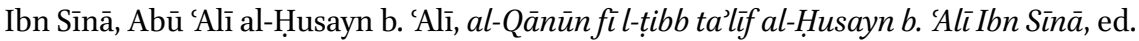
Idwār al-Qashsh, 4 vols, Beirut: 'Izz al-Dīn, 1987.

'Imād al-Dīn, Maḥmūd b. Mas'ūd b. Maḥmūd al-Ṭabīb, Risāla-i ātishak, Ms Tehrān, Majlis 6307, ff. 1-48, copied 2 Rabī II 977/14 September 1569. 
Sennert, Daniel, De Chymicorum cum Aristotelicis eEt Galenicis Consensu ac Dissensu Liber I.: Controversias plurimas tam Philosophis quam Medicis cognitu utiles continens, Wittenberg: Schurerus, 1619.

Al-Ṣuḥārī, Abū Muhạmmad 'Abdallāh b. Muhammad al-Azdī, Kitāb al-mā', awwwal mu'jam țibbì lughawì fi al-tārīkh, ed. Hādī Hasan Hammūdī, 3 vols., 'Umān: alMațba'a al-Sharqiyya, 1996.

Wecker, Johann Jacob, Antidotarium generale et speciale ex optimorum autorum tam veterum quam recentiorum scriptis fideliter et methodice a Ioan. Iacobo Weckero congestum et dispositum, Basel: per Conr. Waldkirch, sumptibus Episcopianorum, 1601. Yūsufī, Mujīb b. Muḥammad b. Yūsuf, Ṭibb-i Yūsufì:Jāmic al-fawā̉id, ed. Ḥusayn Khayrandīsh, Qum: Ibtikār-i Dānish, 2010 (repr. Mu’assasa-i Taḥqīqāt Ḥajāmat).

\section{Secondary Sources}

Afyoncu, Erhan, "Osmanlı Hekimbaşıları ve Hassa Hekimleri," Osmanlılarda Sağlık, Health in the Ottomans, eds. Coşkun Yllmaz and Necdet Yllmaz, Istanbul: Biofarma, 2006, vol. 1, pp. 85-97.

Bachour, Natalia, Oswaldus Crollius und Daniel Sennert im frühneuzeitlichen Istanbul, Studien zur Rezeption des Paracelsismus im Werk des osmanischen Arztes Sālih b. Nașrullāh Ibn Sallūm al-Halabī (Neuere Medizin- und Wissenschaftsgeschichte, vol. 23, Quellen und Studien), Freiburg im Breisgau: Centaurus, 2012.

Bachour, Natalia, "Healing with mercury: the uses of mercury in Arabic medical literature," Asiatische Studien 69/4 (2015), pp. 831-866.

Bachour, Natalia, "Mūmiyā als Arznei im arabischen und osmanischen Schrifttum," Körper, Sexualität und Medizin in islamisch geprägten Gesellschaften, eds. Suzanne Kurz, Claudia Preckel and Stefan Reichmuth, Bamberg: University of Bamberg Press, expected 2016.

Bayat, Ali Haydar, Osmanlı devletinde hekimbaşılı kurumu ve hekimbaşılar, Ankara: Atatürk Kültür Merkezi Başkanlığı, 1999.

Brentjes, Sonja, Travellers from Europe in the Ottoman and Safavid empires, 16 th-17th centuries, seeking, transforming, discarding knowledge, Aldershot: Ashgate Variorum, 2010.

Dash, Bhagwan, Alchemy and metallic medicines in Āyurveda, New Delhi: Concept, 1986.

Düzdağ, Mehmet Ertuğrul (ed.), Şeyhülislâm Ebussuud Efendi fetvaları ısı̆̆ında ı6. asır türk hayatı, 2nd ed., İstanbul: Enderun Kitabevi, 1983.

Elgood, Cyril, "Translation of a Persian monograph on Syphilis entitled Risála-i-átishak by Imád-ul-Dín Mạ̣múd bin Mascúd bin Mạmmúd-ul-Ṭabíb," Annals of Medical History 3 (1931), pp. 465-486.

Friedrich, Christoph and Wolf-Dieter Müller-Jahncke, Geschichte der Pharmazie, Band II: Von der frühen Neuzeit bis zur Gegenwart, Eschborn: Govi, 2005.

Galotta, Aldo, “Khayr al-Dīn ( 
P. Bearman et al., Brill Online, 2014, http://referenceworks.brillonline.com/entries/ encyclopaedia-of-islam-2/khayr-al-din-khidir-pasha-SIM_4258; accessed 21 July 2014.

Günergun, Feza, 14-17. Yüzyıllarda Osmanlı Imparatorluğunda Kullanılan Anorganik İlaçlar. (Inorganic Drugs used in Ottoman Empire during 14-17th Centuries), Istanbul: F. Günergun, 1986.

Günergun, Feza and Dhruv Raina (eds.), Science between Europe and Asia, Historical Studies on the Transmission, Adoption and Adaptation of Knowledge (Boston Studies in the Philosophy of Science, vol. 275), Dordrecht: Springer, 2011.

İhsanoğlu, Ekmeleddin et al. (eds.), Osmanlı tabii ve tatbiki bilimler literatürü tarihi (History of the literature of natural and applied sciences during the Ottoman period), 2 vols, Istanbul: IRCICA, 2006.

İhsanoğlu, Ekmeleddin et al. (eds.), Osmanlı Tıbbi Bilimler Literatürü Tarihi (History of the Literature of Medical Sciences during the Ottoman Period), 4 vols, Istanbul: IRCICA, 2008.

İhsanoğlu, Ekmeleddin et al. (eds.), "Ottoman Science in the Classical Period and Early Contacts with European Science and Technology," Transfer of Modern Science et Technology to the Muslim World, Science and Technology Transfer from the West to the Muslim World from the Renaissance to the Beginning of the Xxth Century (Istanbul 2-4 September 1987), ed. Ekmeleddin İhsanoğlu (Studies and Sources on the History of Science, vol. 5), Istanbul: IRCICA, 1992, pp. 1-48.

Kahya, Esin, "Musa Calinus el-Israili: ein jüdischer Arzt im 16. Jahrhundert," Jüdische Medizin:Jüdisches in der Medizin: Medizin der Juden?, ed. Caris-Petra Heidel, Frankfurt am Main: Mabuse, 2011, pp. 49-56.

Käs, Fabian, Die Mineralien in der arabischen Pharmakognosie, Eine Konkordanz zur mineralischen Materia medica der klassischen arabischen Heilmittelkunde nebst überlieferungsgeschichtlichen Studien, 2 vols (Veröffentlichungen der orientalischen Kommission/Akademie der Wissenschaften und der Literatur (Mainz), vol. 54), Wiesbaden: Harrassowitz Verlag, 2010.

Küçük, Bekir Harun, Contexts and constructions of Ottoman science with special reference to astronomy, Master Sabancı University, İstanbul: [n. p.], 2005.

Lesky, Erna, "Quecksilber," cIBA-Zeitschrift 96 (1959), pp. 3174-3208.

Lev, Efraim, "Trade of Medical Substances in the Medieval and Ottoman Levant (Bilad al-Sham)," Towns and Material Cultures in the Medieval Middle East, ed. Yaacov Lev (Medieval Mediterranean, vol. 39), Leiden: Brill, 2002, pp. 159-184.

Murphey, Rhoads, “Jewish Contribution to Ottoman Medicine, 1450-180o," Jews, Turks, Ottomans: A Shared History, Fifteenth through the Twentieth Century, ed. Avigdor Levy, Syracuse/New York: Syracuse University Press, 2002, pp. 61-74.

Pagel, Walter, Paracelsus: An Introduction to Philosophical Medicine in the Era of the Renaissance, 2nd ed., Basel/Munich: Karger, 1982. 
Porter, Roy, The Greatest Benefit to Mankind, A Medical History of Humanity from Antiquity to the Present, London: Fontana Press, 1999 [1997]1.

Pormann, Peter E., The mirror of health, discovering medicine in the golden age of Islam, London: Royal College of Physicians, 2013.

Sabev, Orlin, "Medical Books in Private and Public Ottoman Libraries," Proceedings of the 38 th International Congress on the History of Medicine (1-6 September 2002), eds. Nil Sarı et al., Ankara, 2005, vol. 2, 615-628.

Sarı, Nil, "Ottoman Medical Practise and the Medical Sciences," Selected Papers on Turkish Medical History, 8th International Congress on the Turkish History of Medicine, 1oth National Congress on the Turkish History of Medicine 20-24 May 2008, Konya, eds. Ayşegül Demirhan Erdemir and Öztan Öncel, Istanbul: n.p., 20o8, pp. 5-89.

Sarı, Nil, Mahmut Gürgan and Zeki İzgüer, "Gedanken zu einer medizinischen Handschrift des osmanischen Arztes Musa Hamon aus dem 16. Jahrhundert," Jüdische Medizin:Jüdisches in der Medizin: Medizin der Juden?, ed. Caris-Petra Heidel, Frankfurt am Main: Mabuse, 2011, pp. 57-68.

Sarı, Nil and Bedizel Zülfikar, "The Paracelsusian Influence on Ottoman Medicine in the Seventeenth and Eighteenth Centuries," Transfer of Modern Science and Technology to the Muslim World, ed. Ekmeleddin İhsanoğlu, Istanbul: n.p., 1992, pp. 157-179.

Savage-Smith, Emilie, "Drug Therapy of Eye Diseases in Seventeenth-Century Islamic Medicine: The Influence of the 'New Chemistry' of the Paracelsians," Pharmacy in History 29 (1987), pp. 3-28.

Schmitz, Rudolf, Geschichte der Pharmazie, Band 1: Von den Anfängen bis zum Ausgang des Mittelalters, with the assistance of Franz-Josef Kuhlen, Eschborn: Govi, 1998.

Schneider, Wolfgang, Lexikon zur Arzneimittelgeschichte Sachwörterbuch zur Geschichte der pharmazeutischen Botanik, Chemie, Mineralogie, Pharmakologie, Zoologie, 7 vols, Frankfurt a. M.: Govi, 1968-1975.

Shefer, Miri, "An Ottoman Physician and his Social and Intellectual Milieu," Studia Islamica n.s. 1 (2011), pp. 133-158.

Shefer-Mossensohn, Miri, Ottoman Medicine: Healing and Medical Institutions, 15001700. Albany: State University of New York Press, 2009.

Shefer-Mossensohn, Miri, "Tobias the Ottoman: Tobias Cohen as an Ottoman Physician," Korot: The Israel Journal of the History of Medicine and Science 20, (2009-2010), pp. $45^{-66 .}$

Sudhoff, Karl, Aus der Frühgeschichte der Syphilis, Handschriften- und Inkunabelstudien, epidemiologische Untersuchung und kritische Gänge (Studien zur Geschichte der Medizin, H. 9), Leipzig: Verlag von Johann Ambrosius Barth, 1912.

Thomann, Johannes, "Early Persian Medical Works on Antisyphilitic Mercury Medicines," Asiatische Studien 69/4 (2015), pp. 971-996.

Ullmann, Manfred, Die Medizin im Islam, Leiden: Brill, 1970.

Ullmann, Manfred, Die Natur- und Geheimwissenschaften im Islam, Leiden: Brill, 1972. 
Wujastyk, Dagmar, "Perfect Medicine: Mercury in Sanskrit Medical Literature," Asian Medicine -Tradition and Modernity 8 (2013), pp. 15-40.

Yılmaz, Coşkun and Necdet Yılmaz (eds.), Osmanlılarda Sağlık, Health in the Ottomans, 2 vols, Istanbul: Biofarma, 2006. 